\title{
SATISFACTION OF PATIENTS \\ WITH FIRST MEDICAL CARE: CROSS-SECTION STUDY (ON THE EXAMPLE OF CITY KYIV)
}

\author{
Valentin Pariy \\ Department of Health Management \\ Institute of Postgraduate Education of the Bogomolets National Medical University \\ 34 Peremohy ave., Kyiv, Ukraine, 01601 \\ Oleksandr Korotkyi \\ Department of Health Management \\ Institute of Postgraduate Education of the Bogomolets National Medical University \\ 34 Peremohy ave., Kyiv, Ukraine, 01601 \\ korotkiy.md@gmail.com
}

\begin{abstract}
After reorganization of ambulatory-polyclinic net of medical institutions in city Kyiv in 2013 and creation of centers of first medical care (FMC), the necessity in monitoring of patients' satisfaction with received first medical care appeared.

Aim. To estimate satisfaction of patients of FMC Centers of city Kyiv with received first medical care, to compare it with patients' satisfaction in rural area of Ukraine and in European Union countries.

Materials and methods. The cross-section study was realized in FMC centers of city Kyiv during 6 months of 2017 year. In total 397 persons, 18 years old and more, who addressed to doctors of the first link during no less than one year, were selected for the study. The used EUROPEP instrument, the questionnaire, consists of 23 questions with their possible assessment by Likert five-point scale and includes the following aspects: doctor-patient-relationship, assessment of direct medical care, information and support of a patient by a doctor, organization aspects of care, its accessibility. The internal succession of the questionnaire Cronbach's alpha was estimated, and its reliability was checked. Main indices of research results were mean EUROPEP indices (minimum 1, maximum 5).

Results. The study has established, that satisfaction of Ukrainian patients with FMC (index $-75,5 \%$ ) is statistically reliably lower than indices of European Union countries. In average, only 37,16 \% of respondents estimated the level of received FMC as "perfect" and correspondingly $38,35 \%$ of patients as "good". There were revealed problems with an access to medical care, namely: "Time of waiting for a consultation near a cabinet" received the least mark (3,29 and 45,59 \% respectively), "Possibility of registration for consultation by phone" is also low (3,47 and 59,95\% respectively). Problems in communications, the low level of trust and doctor's authority were revealed in the decreased index "Doctor's help in fighting against negative emotions, connected with your health status" (3,72 and 56,17 \% respectively). There was studied, that in Ukraine satisfaction of patients, who live in rural area, is statistically reliably lower than Kyiv indices.

Conclusion. The study of satisfaction of patients with received FMC revealed imperfection of the existing system of first medical care. The research results may be used at elaborating new functional-organizational model of activity of first medical care, including patients' satisfaction as an important component in the integrative dimension of the medical help quality.
\end{abstract}

Keywords: first medical care, EUROPEP questionnaire, satisfaction.

\section{Introduction}

Modern models of health protection systems involve patients in the process of making decisions and giving services more and more often [1]. The determination of the level of received medical help by patients is recognized as more important from the point of view of integral estimation of the quality of given medical services [2]. Numerous international studies consider the determination and estimation of patients' satisfaction with received medical care as a component that forms the model of doctor-patient relationship and communications [3]. The survey of available literature allows to connect patients' satisfaction with communication skills of doctors of the first link, formation of relations between patients and doctors, based on trust and continuous support that finally results in the growth of compliance level and patient's observance of instructions and increase of treatment results [4]. Thus, patients' satisfaction itself is usually a multi-dimensional construction and became an important indicator of the first medical care quality [5]. Patients' estimation of re- 
ceived medical care is more and more appreciated by policy providers in health protection sphere, administrators and doctors-practicians as an opinion about a quality together with such indicators as morbidity, mortality, life quality and charges for health protection [6].

For the present there is no universal gold standard for estimating the level of patients' satisfaction. Studies of patients' satisfaction, realized in European region, used the standard instrument EUROPEP (The European Task Force on Patient Evaluations of General Practice Care), henceforward accessible for international comparisons [7]. Using this instrument, it is possible to determine spheres in first medical care that need improvement [8]. It was studied, that the level of patients' satisfaction is connected with their access to medical care [9]. But it must be taken into account, that the high satisfaction of patients is not obligatory equivalent to the high quality of medical care [10]. Satisfaction of consumers of medical services under conditions of health protection sphere reformation in Ukraine becomes more and more important, although it is not typical for today to include patients' satisfaction to criteria that help to estimate the quality of first medical care [11].

Studies of patients' satisfaction using standard methods are not numerous in Ukraine and realized mainly among the rural population [12].

\section{Aim of research}

To estimate satisfaction of patients of FMC Centers of city Kyiv with received first medical care, to compare it with patients' satisfaction in European Union countries.

\section{Materials and methods}

The descriptive cross-sectional social-hygienic study was realized using the questionnaire-interrogating method [13].

The cross-sectional study was realized in first medical care centers of city Kyiv during 6 months of 2017 year. In total 397 forms of persons, 18 years old and more, who addressed to doctors of the first link during no less than one year for the moment of the study, were selected for the study.

The used EUROPEP instrument, the questionnaire, consists of 23 questions with their possible assessment by Likert five-point scale and includes the following aspects: doctor-patient-relationship, assessment of direct medical care, information and support of a patient by a doctor, organization of care, its accessibility. The internal succession of the questionnaire Cronbach's alpha was estimated, and its reliability was checked. Main indices of research results were mean EUROPEP indices (minimum 1, maximum 5).

The circulation of forms among patients, who expressed their desire to speak their mind, was realized by doctors and medical nurses after the end of visiting a patient. For minimization of the influence of medical workers and prevention of bias at filling a form, patients were offered to do it at home and to put it in a special container, placed near an entry in a medical institution, at a repeated visit. The questionnaire was anonymous. None personal data were collected and used by us.

Descriptive statistic parameters (mean, \pm standard deviation, \pm standard error of mean) and percents were calculated. Internal coordination was estimated by Cronbach's alpha and mean correlation between elements. Cronbach's alpha 8 was determined as the least acceptable value. Data were processed by software STATISTICA StarSoft, Inc. та MS Excel. The level of statistical reliability was established at the level $p<0,05$. We have calculated the percent of respondent for each question, supposing that the question coefficient $90-100 \%$ as good, $80-90 \%$ - as acceptable, and $<80 \%$ - as problem one [14].

According to the reviewed instrument EUROPEP-2006 and user's study guide, we have accepted the assessment of points of the scale at the level of $75 \%$ or higher that is the percent of patient's positive marks ( 4 or 5 on Likert scale), that corresponds to answers "perfect" and "good" [15].

\section{Results of research}

It was established, that internal coordination (Cronbach's alpha for the Ukrainian EUROPEP-instrument is 0,93 . In total 470 forms were offered for filling. The frequency of patients' responses was 411 forms that is $87,4 \%$. 14 forms were recognized as invalid that is $3,5 \% .397$ forms $(\mathrm{n}=397)$ were recognized as valid and processed. The distribution by sex included $106(26,7 \%)$ 
male persons and 291 (73,3 \%) female persons. The distribution by age is following: persons, younger than 30 years - $83(20,9 \%), 31-40$ years old $-131(33,0 \%), 41-50$ years old $-78(19,6 \%)$, 51-60 years old - $48(12,1 \%)$, persons, older than 60 years $-57(14,45 \%)$. The distribution by education level is following: persons with primary education $6(1,5 \%)$, with the middle level of education - 159 (40,1\%), graduates of higher educational institutions - $232(58,4 \%)$ (Table 1).

Table 1

Characteristic of patients ( $\mathrm{n}=397)$, who finished the questionnaire

$\begin{array}{ll}\text { Characteristic of patients } & \text { No. (\%) patients }\end{array}$

\section{Sex:}

1. 1. Women

1. 2. Men

2. Education level:

2. 1. Primary

2. 2. Middle

2. 3. Higher

$232(58,4)$

\section{Age}

3. $1 .<30$ years

$83(20,9)$

3. 2. 31-40 years

$131(33,0)$

3. $3.41-50$ years

3. 4. 51-60 years

3. $5 .>60$ years

\section{Own estimation of health status}

4. 1. Perfect

4. 2. Good

$159(40,1)$

4. 3. Satisfactory

$149(37,5)$

4. 4. Unsatisfactory

$61(15,4)$

\section{Employment}

\section{1. Working person}

5. 2. Not working person

\section{Assessed:}

6. 1. Family doctor

$201(50,6)$

6. 2. District therapeutist

6. 3. District pediatrician

$158(39,8)$

At comparing mean values, obtained as a result of the study with published data as to EUROPEP-questionnaire results in some EU countries (FRG, Denmark, Norway, Bulgaria), and also of the native study of satisfaction of the rural population, we revealed statistically reliable differences $(p<0,01)$ of mean values among all studied countries, except Denmark (Table 2).

The index of specific weight of patients with answers 4 and 5 by Likert scale, that allows to compare patients' satisfaction with received FMC with patients of $8 \mathrm{EU}$ countries and that is also statistically reliably lower $(\mathrm{p}<0,01)$, than in developed EU countries was calculated (Table 3). 
Table 2

Descriptive statistics, comparison of obtained results (mean values) with ones of previous studies in separate EU countries

\begin{tabular}{|c|c|c|c|c|c|c|c|c|c|c|}
\hline \multirow[b]{2}{*}{$\begin{array}{c}\text { Ukrainian } \\
\text { EUROPEP-instrument, } \\
\text { assessment } \\
\text { aspect of FMC }\end{array}$} & \multirow[b]{2}{*}{$\begin{array}{c}\text { No. } \\
(\%) \text { of } \\
\text { missed } \\
\text { answers }\end{array}$} & \multirow[b]{2}{*}{$\begin{array}{l}\text { Ukraine, } \\
\text { Kyiv, } \\
\text { mean } \\
(\mathrm{M})\end{array}$} & \multirow[b]{2}{*}{$\begin{array}{l}\text { Standard } \\
\text { deviation, } \\
\text { (SD) }\end{array}$} & \multirow[b]{2}{*}{$\begin{array}{l}\text { Standard } \\
\text { error, }(m)\end{array}$} & \multirow[b]{2}{*}{$\begin{array}{l}\text { Coeffi- } \\
\text { cient of } \\
\text { variant, } \\
(\%)\end{array}$} & \multicolumn{5}{|c|}{ Data of previous studies } \\
\hline & & & & & & $\begin{array}{l}\text { Ukraine } \\
\text { (rural popu- } \\
\text { lation), mean } \\
\text { (M) [12] }\end{array}$ & $\begin{array}{r}\text { Eu } \\
\text { FRG } \\
{[16]}\end{array}$ & $\begin{array}{l}\text { Denmark } \\
\text { [17] }\end{array}$ & $\begin{array}{l}\text { nion cou } \\
\text { Norway } \\
\text { [18] }\end{array}$ & $\begin{array}{l}\text { ntries } \\
\text { Bulgaria } \\
{[8]}\end{array}$ \\
\hline 1 & 2 & 3 & 4 & 5 & 6 & 7 & 8 & 9 & 10 & 11 \\
\hline $\begin{array}{l}\text { (Doctor-patient- } \\
\text { relationship) } \\
\text { Cronbach's } \alpha=0,81\end{array}$ & & 4,06 & & & & 3,57 & 4,52 & $4,29 *$ & 4,44 & 4,40 \\
\hline $\begin{array}{l}\text { Feeling that time, given } \\
\text { to you for a consultation } \\
\text { by a doctor, is } \\
\text { enough (Q1) }\end{array}$ & $11(2,77)$ & 3,97 & 0,96 & 0,05 & 24,19 & 3,71 & 4,4 & $4,16 *$ & 4,18 & 4,35 \\
\hline $\begin{array}{l}\text { Doctor's interest } \\
\text { in your individual } \\
\text { situation }(\mathbf{Q 2})\end{array}$ & $16(4,03)$ & 4,10 & 0,94 & 0,05 & 22,91 & 3,44 & 4,5 & $4,23 *$ & 4,5 & 4,36 \\
\hline $\begin{array}{l}\text { Favoring of easy com- } \\
\text { munication with your } \\
\text { about your problems by a } \\
\text { doctor (Q3) }\end{array}$ & $21(5,29)$ & 4,03 & 1,00 & 0,05 & 24,93 & 3,41 & 4,5 & $4,22 *$ & 4,45 & 4,36 \\
\hline $\begin{array}{l}\text { Your involvement } \\
\text { in decision making as to } \\
\text { medical care by } \\
\text { a doctor }(\mathbf{Q} 4)\end{array}$ & $31(7,81)$ & 3,91 & 1,14 & 0,06 & 29,04 & 2,93 & 4,4 & $4,15^{*}$ & 4,37 & 4,3 \\
\hline $\begin{array}{l}\text { Attentive listening to } \\
\text { you by a doctor (Q5) }\end{array}$ & $5(1,26)$ & 4,36 & 0,79 & 0,04 & 18,11 & 4,09 & 4,6 & $4,31 *$ & 4,54 & 4,49 \\
\hline $\begin{array}{l}\text { Providing of confidenti- } \\
\text { ality of records and } \\
\text { your personal data by } \\
\text { a doctor (Q6) }\end{array}$ & $\begin{array}{c}45 \\
(11,34)\end{array}$ & 3,98 & 1,25 & 0,06 & 31,36 & 3,82 & 4,7 & $4,68^{*}$ & 4,6 & 4,55 \\
\hline $\begin{array}{l}\text { Assessment of direct } \\
\text { Medical care Cron- } \\
\text { bach's } \alpha=0,85\end{array}$ & & 4,14 & & & & 3,51 & 4,28 & $4,12 *$ & 4,34 & 4,34 \\
\hline $\begin{array}{l}\text { Fast relief of } \\
\text { your condition by } \\
\text { a doctor }(\mathbf{Q 7})\end{array}$ & $19(4,79)$ & 4,10 & 0,98 & 0,05 & 23,80 & 3,34 & 4,4 & $4,03 *$ & 4,22 & 4,33 \\
\hline $\begin{array}{c}\text { Doctor's care } \\
\text { improves your health in } \\
\text { such a way that results } \\
\text { in your return to routine } \\
\text { life }(\mathbf{Q 8 )}\end{array}$ & $26(6,55)$ & 4,04 & 1,06 & 0,05 & 26,13 & 3,3 & 4,4 & $4,04 *$ & 4,31 & 4,33 \\
\hline $\begin{array}{c}\text { Doctor's carefulness } \\
\text { relative to your } \\
\text { problems (Q9) }\end{array}$ & $12(3,02)$ & 4,16 & 0,91 & 0,05 & 21,91 & 3,62 & 4,3 & $4,27 *$ & 4,48 & 4,33 \\
\hline $\begin{array}{l}\text { Quality of your } \\
\text { examination by } \\
\text { a doctor }(\mathbf{Q 1 0})\end{array}$ & $6(1,51)$ & 4,31 & 0,82 & 0,04 & 19,02 & 4,18 & 4,2 & $4,23 *$ & 4,42 & 4,38 \\
\hline $\begin{array}{l}\text { Offering of services on } \\
\text { prophylaxis of diseases } \\
\text { (additional examinations, } \\
\text { prophylactic inspections, } \\
\text { vaccination) (Q11) }\end{array}$ & $21(5,29)$ & 4,11 & 1,03 & 0,05 & 24,98 & 3,09 & 4,1 & $4,05^{*}$ & 4,27 & 4,34 \\
\hline $\begin{array}{c}\text { Information and } \\
\text { support of a patient by } \\
\text { a doctor Cronbach's } \\
\qquad \alpha=0,81\end{array}$ & & 4,06 & & & & 3,20 & 4,40 & $4,13^{*}$ & 4,34 & 4,27 \\
\hline
\end{tabular}




\section{Continuation of the Table 2}

\begin{tabular}{|c|c|c|c|c|c|c|c|c|c|c|}
\hline 1 & 2 & 3 & 4 & 5 & 6 & 7 & 8 & 9 & 10 & 11 \\
\hline $\begin{array}{l}\text { Explication of } \\
\text { the aim of inspections, } \\
\text { examinations and } \\
\text { treating methods by } \\
\text { a doctor (Q12) }\end{array}$ & $16(4,03)$ & 4,20 & 0,96 & 0,05 & 22,78 & 3,67 & 4,4 & $4,2 *$ & 4,37 & 4,31 \\
\hline $\begin{array}{c}\text { Sufficient information } \\
\text { about your symptoms } \\
\text { and/or diseases by a } \\
\text { doctor (Q13) }\end{array}$ & $9(2,27)$ & 4,20 & 0,86 & 0,04 & 20,49 & 3,13 & 4,4 & $4,1^{*}$ & 4,39 & 4,31 \\
\hline $\begin{array}{l}\text { Doctor's help in } \\
\text { fighting against negative } \\
\text { emotions, connected } \\
\text { with your health condi- } \\
\text { tion (Q14) }\end{array}$ & $8(2,02)$ & 3,72 & 0,87 & 0,04 & 23,29 & 2,91 & 4,3 & $4,04 *$ & 4,29 & 4,18 \\
\hline $\begin{array}{l}\text { Help in understanding, } \\
\text { why it is important to } \\
\text { observe doctor's recom- } \\
\text { mendations (Q15) }\end{array}$ & $21(5,29)$ & 4,11 & 1,00 & 0,05 & 24,40 & 3,08 & 4,5 & $4,16^{*}$ & 4,32 & 4,26 \\
\hline $\begin{array}{c}\text { Organization aspects } \\
\text { of medical care } \\
\text { Cronbach's } \alpha=0,8\end{array}$ & & 4,08 & & & & 3,08 & 4,25 & $4,01 *$ & 4,27 & 4,29 \\
\hline $\begin{array}{c}\text { Doctor's knowledge } \\
\text { about what was done } \\
\text { (said) to your at previous } \\
\text { visit (Q16) }\end{array}$ & $21(5,29)$ & 4,08 & 1,00 & 0,05 & 24,41 & 3,02 & 4,3 & $4,05^{*}$ & 4,28 & 4,31 \\
\hline $\begin{array}{l}\text { Doctor's explanatory } \\
\text { work about what is ex- } \\
\text { pected at your direction } \\
\text { to profile specialists, } \\
\text { institutions that give } \\
\text { stationary care and other } \\
\text { providers of medical } \\
\text { services (Q17) }\end{array}$ & $24(6,05)$ & 4,07 & 1,04 & 0,05 & 25,62 & 3,13 & 4,2 & $3,97 *$ & 4,25 & 4,27 \\
\hline $\begin{array}{l}\text { Accessibility of first } \\
\text { medical help Cron- } \\
\text { bach's } \alpha=0,82\end{array}$ & & 3,65 & & & & 2,73 & 3,73 & $3,78 *$ & 4,32 & 4,18 \\
\hline $\begin{array}{l}\text { Kindness, politeness of } \\
\text { medical staff (except } \\
\text { a doctor) relative to } \\
\text { you (Q18) }\end{array}$ & $7(1,76)$ & 4,36 & 0,82 & 0,04 & 18,69 & 3,58 & 4,4 & $4,06^{*}$ & 4,56 & 4,27 \\
\hline $\begin{array}{l}\text { Possibility of being } \\
\text { invited to a doctor in } \\
\text { comfortable time (Q19) }\end{array}$ & $\begin{array}{c}48 \\
(12,09)\end{array}$ & 3,61 & 1,29 & 0,06 & 35,62 & 2,58 & 4,30 & $3,92 *$ & 4,46 & 4,18 \\
\hline $\begin{array}{l}\text { Possibility of } \\
\text { registration for visiting } \\
\text { a doctor by phone (Q20) }\end{array}$ & $\begin{array}{c}60 \\
(15,11)\end{array}$ & 3,47 & 1,46 & 0,07 & 42,13 & 2,35 & 2,80 & $3,4^{*}$ & 4,5 & 4,32 \\
\hline $\begin{array}{l}\text { Possibility to talk with } \\
\text { a doctor by phone (Q21) }\end{array}$ & $\begin{array}{c}60 \\
(15,11)\end{array}$ & 3,54 & 1,43 & 0,07 & 40,27 & 2,16 & 3,10 & $3,56^{*}$ & 4,18 & 4,39 \\
\hline $\begin{array}{l}\text { Time of waiting for } \\
\text { a consultation near } \\
\text { a cabinet (Q22) }\end{array}$ & $16(4,03)$ & 3,29 & 1,13 & 0,06 & 34,18 & 2,39 & 3,40 & $3,49 *$ & 3,73 & 3,65 \\
\hline $\begin{array}{c}\text { Emergency } \\
\text { services }(\mathbf{Q 2 3})\end{array}$ & $\begin{array}{c}65 \\
(16,41)\end{array}$ & 3,63 & 1,38 & 0,07 & 38,07 & 3,31 & 4,40 & $4,22 *$ & 4,51 & 4,28 \\
\hline
\end{tabular}

Note: *-differences between mean values are not reliable $(p>0,05)$ 
Table 3

Descriptive characteristic, comparison of obtained results (percents) with ones of previous studies in 8 EU countries

\begin{tabular}{|c|c|c|c|c|c|c|c|c|}
\hline \multirow{2}{*}{$\begin{array}{l}\text { Ukrainian } \\
\text { EUROPEP- } \\
\text { instrument, } \\
\text { quality aspect of } \\
\text { FMC quality }\end{array}$} & \multicolumn{5}{|c|}{ Assessment of FMC in city Kyiv in 2017, ( \%) } & \multirow{2}{*}{$\begin{array}{l}\text { Specific weight } \\
\text { of patient with } \\
\text { answers } 4 \text { and } \\
5 \text { by Likert } \\
\text { scale, ( \%) }\end{array}$} & \multicolumn{2}{|c|}{$\begin{array}{c}\text { Indices of } \\
8 \text { EU countries }[8]\end{array}$} \\
\hline & Bad (1) & $\begin{array}{c}\text { Unsatisfactory } \\
\text { (2) }\end{array}$ & $\begin{array}{c}\text { Satisfactory } \\
\text { (3) }\end{array}$ & $\begin{array}{c}\text { Good } \\
\text { (4) }\end{array}$ & $\begin{array}{l}\text { Perfect } \\
\text { (5) }\end{array}$ & & Interval & Mean, \% \\
\hline (Q1) & 0,25 & 2,52 & 21,91 & 39,29 & 33,25 & 72,54 & $(87,4-95,1)$ & 89,6 \\
\hline (Q2) & 0,00 & 0,50 & 13,85 & 44,33 & 37,28 & 81,61 & $(77,1-95,2)$ & 87,9 \\
\hline (Q3) & 0,00 & 0,25 & 16,62 & 42,32 & 35,52 & 77,83 & $(85,1-93,9)$ & 89,2 \\
\hline (Q4) & 0,25 & 2,02 & 14,86 & 40,55 & 34,51 & 75,06 & $(83,2-93,7)$ & 86,9 \\
\hline (Q5) & 0,00 & 0,25 & 11,34 & 35,52 & 51,64 & 87,15 & $(88,0-95,3)$ & 91,6 \\
\hline (Q6) & 0,00 & 0,00 & 10,83 & 34,51 & 43,32 & 77,83 & $(91,2-97,0)$ & 94,7 \\
\hline (Q7) & 0,00 & 0,50 & 12,85 & 43,32 & 38,54 & 81,86 & $(75,3-92,8)$ & 86,5 \\
\hline (Q8) & 0,00 & 0,25 & 13,85 & 41,81 & 37,53 & 79,35 & $(83,4-93,6)$ & 88,5 \\
\hline (Q9) & 0,00 & 0,25 & 15,87 & 39,04 & 41,81 & 80,86 & $(84,8-94,4)$ & 89,8 \\
\hline (Q10) & 0,00 & 0,25 & 13,10 & 36,27 & 48,87 & 85,14 & $(82,4-94,4)$ & 88,9 \\
\hline (Q11) & 0,00 & 0,50 & 14,61 & 37,53 & 42,07 & 79,60 & $(79,9-90,3)$ & 86,7 \\
\hline (Q12) & 0,00 & 0,25 & 12,85 & 37,53 & 45,34 & 82,87 & Not applied & Not applied \\
\hline (Q13) & 0,00 & 0,76 & 13,10 & 42,07 & 41,81 & 83,88 & $(83,3-96,2)$ & 89,1 \\
\hline (Q14) & 0,00 & 0,76 & 41,06 & 35,52 & 20,65 & 56,17 & $(72,6-91,1)$ & 83,2 \\
\hline (Q15) & 0,00 & 0,00 & 13,60 & 40,30 & 40,81 & 81,11 & $(82,1-93,1)$ & 87,3 \\
\hline (Q16) & 0,00 & 0,00 & 14,11 & 42,32 & 38,29 & 80,60 & $(78,3-91,2)$ & 85,9 \\
\hline (Q17) & 0,00 & 0,50 & 13,35 & 40,81 & 39,29 & 80,10 & Not applied & Not applied \\
\hline (Q18) & 0,00 & 0,25 & 10,33 & 35,77 & 51,89 & 87,66 & $(83,8-94,6)$ & 89,9 \\
\hline (Q19) & 1,51 & 3,78 & 16,62 & 39,55 & 26,45 & 65,99 & $(76,0-97,4)$ & 88,6 \\
\hline (Q20) & 3,53 & 7,05 & 14,36 & 28,46 & 31,49 & 59,95 & $(65,4-95,6)$ & 86,3 \\
\hline (Q21) & 2,52 & 5,54 & 12,59 & 33,25 & 30,98 & 64,23 & $(68,6-94,3)$ & 82,7 \\
\hline (Q22) & 4,79 & 12,85 & 32,75 & 31,99 & 13,60 & 45,59 & $(63,9-82,9)$ & 72,1 \\
\hline \multirow[t]{2}{*}{ (Q23) } & 0,76 & 1,77 & 11,36 & 39,90 & 29,80 & 69,70 & $(84,0-98,0)$ & 91,7 \\
\hline & \multicolumn{3}{|c|}{ Mean value } & & & 75,51 & & \\
\hline
\end{tabular}

\section{Discussion of research results}

The lowest mark was received by answers on questions "Time of waiting near for a consultation a cabinet" $(3,29)$, "Possibility of registration for a consultation by phone" $(3,47)$, "Possibility of speaking with a doctor by phone" $(3,54)$, "Possibility of being invited to a doctor in a comfortable time" $(3,61)$, that may testify to the unsatisfactory availability of first medical care. The demonstrative moment is the low mark of "Doctor's help in fighting against negative emotions, connected with your health status" $(3,72)$, that may testify to the insufficient level of communications in the system "doctor-patient", low level of trust and doctor's authority. 
The lowest patients' satisfaction with first medical help by all 5 studied parameters among studied countries was fixed in Ukraine (at that it was essentially lower in rural area than in the city, $\mathrm{p}<0,01$ ) (Fig. 1).

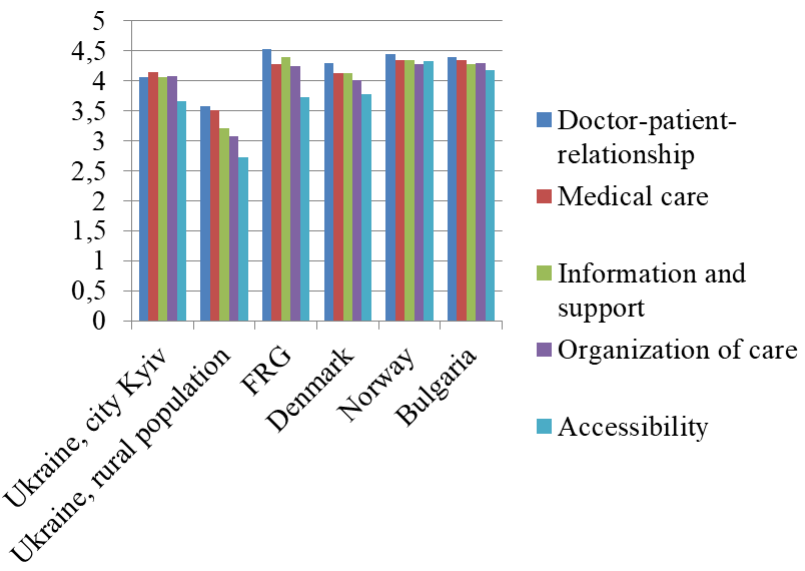

Fig. 1. Patients' satisfaction with FMC in the section of Ukraine and several EU countries, (M)

The low mark was received by answers on questions "Time of waiting for a consultation near a cabinet" (45,59), "Possibility of registration for a consultation by phone" $(59,95)$, "Possibility of speaking with a doctor by phone" $(64,23)$, "Possibility of being invited to a doctor in a comfortable time" $(65,99)$, that may testify to the unsatisfactory availability of first medical care. The mark of "Doctor's help in fighting against negative emotions, connected with your health status" is also low $(56,17)$, that may be a result of unsatisfactory communicative skills of a doctor that must be improved [19]. In 2011 year the study with EUROPEP instrument was realized in 8 European countries [8]. The comparison of our research of 2017 with European data is presented on Fig. 2. It was established, that satisfaction of Ukrainian patients with FMC is essentially lower than in developed European countries [20].

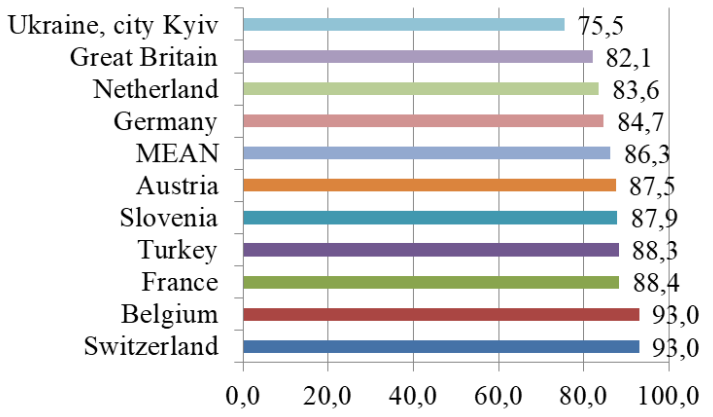

Fig. 2. Comparison of patients' satisfaction with FMC among European countries, (\%)

It is necessary to note, that this cross-section research has several limitations. In total the sample is not representative for the general population. The frequency of answers to questions was low; so, its results may influence the answers' shift. Based on it, it is supposed, that the results of the general estimation and comparability of patients may be deformed or asymmetric. So, the addition or correction may be attained due to expert discussions and at lager testing in future.

\section{Conclusion}

1. The study established, that satisfaction of patients in Ukraine with received FMC (index $-75,5 \%)$ is statistically reliably lower than indices of countries of European Union. In 
average, only $37,16 \%$ of respondents estimated the level of FMC as "perfect" and correspondingly $38,35 \%$ of patients is "good". There were revealed problems with an access to medical care, namely "Time of waiting for a consultation near a cabinet" had the lowest mark (3,29 and $45,59 \%$ respectively), "Possibility of registration for a consultation by phone" $(3,47)$, "Possibility of speaking with a doctor by phone" is also low (3,54 and 59,95\%, respectively). Problems of communications and the low level of trust and doctor's authority were reflected in the low index of "Doctor's help in fighting against negative emotions, connected with your health status" (3,72 and $56,17 \%$ respectively).

2. It was fixed, that satisfaction of patients, who live in rural area in Ukraine is statistically reliably lower than indices of city Kyiv.

3. The study of patients' satisfaction with received first medical care revealed imperfectness of the existing system of first medical care. The results of the research may be used at elaborating the new functional-organizational model of first medical care, taking into account patients' satisfaction as an important component in the integrative dimension of the first medical care quality.

\section{References} EgitimVakfi.

[1] Coruh, M. (1996). Total quality management in primary care practice. Ankara: Haberal

[2] Van Royen, P., Rees, C. E., Groenewegen, P. (2014). Patient-centred interprofessional collaboration in primary care: challenges for clinical, educational and health services research. An EGPRN keynote paper. European Journal of General Practice, 20 (4), 327-332. doi: 10.3109/13814788.2014.908462

[3] Kinnersley, P., Stott, N., Peters, T., Harvey, I., Hackett, P. (1996). A comparison of methods for measuring patient satisfaction with consultations in primary care. Family Practice, 13 (1), 41-51. doi: 10.1093/ fampra/13.1.41

[4] Baker, R. (1996). Characteristics of practices, general practitioners and patients related to levels of patients' satisfaction with consultations. British Journal of General Practice, 46 (411), 601-605.

[5] Roque, H., Veloso, A., Ferreira, P. L. (2016). Portuguese version of the EUROPEP questionnaire: contributions to the psychometric validation. Revista de Saude Publica, 50, 61. doi: 10.1590/s15188787.2016050006259

[6] Grol, R., Wensing, M., Mainz, J. et. al. (2000). Patients in Europe evaluate general practice care: an international comparison. British Journal of General Practice, 50 (460), 882-887.

[7] Wensing, M., Mainz, J., Grol, R. (2000). A standardised instrument for patient evaluations of general practice care in Europe. European Journal of General Practice, 6 (3), 82-87. doi: 10.3109/ 13814780009069953

[8] Dimova, R., Stoyanova, R., Keskinova, D. (2017). The EUROPEP questionnaire for patient's evaluation of general practice care: Bulgarian experience. Croatian Medical Journal, 58 (1), 63-74. Available at: https://www.ncbi.nlm.nih.gov/pmc/articles/PMC5346897/ doi: 10.3325/cmj.2017.58.63

[9] Mortsiefer, A., Altiner, A., Ernst, A., Kadusziewicz, H., Krahe, A., Mellert, C. et. al. (2017). Satisfaction with general practice care in German patients with multimorbidity: a cross-sectional study. Family Practice, 34 (4), 452-458. doi: 10.1093/fampra/cmw141

[10] Akturk, Z., Atesoglu, D., Ciftci, E. (2015). Patient satisfaction with family practice in Turkey: Three-year trend from 2010 to 2012. European Journal of General Practice, 21 (4), 238-245. doi: 10.3109/13 814788.2015 .1048681

[11] Williams, S. J., Calnan, M. (1991). Key Determinants of Consumer Satisfaction With General Practice. Family Practice, 8 (3), 237-242. doi: 10.1093/fampra/8.3.237

[12] Odrynskyi, V. A. (2015). Medyko-socialne obg'runtuvannia modeli pervynnoi medyko-sanitarnoi dopomogy silskomu naselenniu na rivni administratyvnogo raionu. Nacionalna medychna akademiia pisliadyplomnoi osvity imeni P. L. Shupyka. Kyiv, 197.

[13] Tavakyn, E. P. (2009). Osnovy metodyky sociologicheskogo issledovaniia. Moscow: YNFRA-M, 239. 
[14] Wensing, M., Mainz, J., Grol, R. (2000). A standardised instrument for patient evaluations of general practice care in Europe. European Journal of General Practice, 6 (3), 82-87. doi: $10.3109 / 13814780009069953$

[15] EUROPEP (2006). Revised Europep instrument and user manual. Center for Quality of Care Research, Michel Weinsing (co-ordinator). Available at: http://www.equip.ch/files/25/europep 2006rapport.pdf

[16] Szecsenyi, J., Goetz, K., Campbell, S., Broge, B., Reuschenbach, B., Wensing, M. (2011). Is the job satisfaction of primary care team members associated with patient satisfaction? BMJ Quality \& Safety, 20 (6), 508-514. Available at: http://qualitysafety.bmj.com/content/20/6/508 doi: 10.1136/ bmjqs.2009.038166

[17] Vedsted, P., Sokolowski, I., Heje, H. N. (2008). Data quality and confirmatory factor analysis of the Danish EUROPEP questionnaire on patient evaluation of general practice. Scandinavian Journal of Primary Health Care, 26 (3), 174-180. doi: 10.1080/02813430802294803

[18] Bjertnaes, O. A., Lyngstad, I., Malterud, K., Garratt, A. (2010). The Norwegian EUROPEP questionnaire for patient evaluation of general practice: data quality, reliability and construct validity. Family Practice, 28 (3), 342-349. Available at: http://fampra.oxfordjournals.org/content/early/2010/11/15/fampra. cmq098.full doi: 10.1093/fampra/cmq098

[19] King, A., Hoppe, R. B. (2013). "Best Practice" for Patient-Centered Communication: A Narrative Review. Journal of Graduate Medical Education, 5 (3), 385-393. doi: 10.4300/jgmed-13-00072.1

[20] Petek, D., Kunzi, B., Kersnik, J., Szecsenyi, J., Wensing, M. (2011). Patients' evaluations of European general practice-revisited after 11 years. International Journal for Quality in Health Care, 23 (6), $621-628$. 